Abstracta Iranica Abstracta Iranica

Revue bibliographique pour le domaine irano-aryen

Volume 22 | 2001

Comptes rendus des publications de 1999

Tacheh of Chahar Mahal (trad. du persan par Amin Neshati). Tehrân, Yassavoli Publications, 1998, 47 p. +60 pl. h.-t., $22 \times 23,5 \mathrm{~cm}$.

Jean-Pierre Digard

(2) OpenEdition

Journals

Édition électronique

URL : http://journals.openedition.org/abstractairanica/37357

DOI : 10.4000/abstractairanica.37357

ISSN : 1961-960X

Éditeur :

CNRS (UMR 7528 Mondes iraniens et indiens), Éditions de l'IFRI

Édition imprimée

Date de publication : 15 mai 2001

ISSN : 0240-8910

Référence électronique

Jean-Pierre Digard, " Tacheh of Chahar Mahal (trad. du persan par Amin Neshati). Tehrân, Yassavoli Publications, 1998, 47 p. +60 pl. h.-t., 22 × 23,5 cm. », Abstracta Iranica [En ligne], Volume 22 | 2001, document 649, mis en ligne le 17 février 2010, consulté le 13 octobre 2020. URL : http:// journals.openedition.org/abstractairanica/37357; DOI : https://doi.org/10.4000/abstractairanica. 37357

Ce document a été généré automatiquement le 13 octobre 2020.

Tous droits réservés 


\title{
Tacheh of Chahar Mahal (trad. du persan par Amin Neshati). Tehrân, Yassavoli Publications, 1998, 47 p. + 60 pl. h.-t., $22 \times 23,5 \mathrm{~cm}$.
}

\author{
Jean-Pierre Digard
}

Ce petit ouvrage est consacré à des pièces de tissage du Čahār-Mahāāl apparues, écrit l'A., au bâzâr de Téhéran en 1991. En dépit de l'exégèse esthétique et symbolique à laquelle s'évertue P. Tanāvolī, la plupart de ces pièces ne sont rien d'autre que des bissacs (Hūrjīn) ou des poches de bissacs de qualité moyenne, utilisés par les nomades pour transporter du grain ou de la farine, ici décousus et dépliés pour être présentés à plat, comme des œuvres originales, aux acheteurs et courtiers occidentaux (l'arrivée subite de ces tissages strictement utilitaires dans les bâzârs pourrait être liée, selon moi, à la sédentarisation massive des nomades à partir de la fin des années 1980). Le livre de P. Tanāvolī vaut plus pour la qualité de ses photographies en couleurs que pour son intérêt documentaire, qui est pour le moins inégal et incertain. Après la « découverte » et la promotion commerciale des gabbehs dans les années 1970, allonsnous maintenant assister à celles des bissacs recyclés sous l'appellation de tachehs (mot que je n'ai, pour ma part, jamais entendu prononcer chez les Bakhtiyâri)?

\section{INDEX}

Thèmes : 16.1. Iran 
AUTEURS

JEAN-PIERRE DIGARD

CNRS - Paris 